\title{
DEPOLARIZATION-INDUCED SYNAPTIC PLASTICITY AT CHOLINERGIC SYNAPSES IN TISSUE CULTURE ${ }^{1}$
}

\author{
MARK C. FISHMAN ${ }^{2}$ AND PHILLIP G. NELSON
}

Laboratory of Developmental Neurobiology, National Institutes of Health, Bethesda, Maryland 20205

\begin{abstract}
Many synaptic connections are rejected during development, and the remainder are stabilized. Whether neuronal activity is important in this remodeling remains unknown. Cholinergic synapses are formed in tissue culture between the hybrid NG108-15 (neuroblastoma $\times$ glioma) cell and skeletal myotubes. We have investigated changes in these synapses brought about by chronic depolarization. Most myotubes are innervated under control conditions and recording from a myotube while stimulating a neighboring hybrid cell demonstrates that most hybrid-myotube pairs in anatomical proximity also are connected synaptically. Multiple innervation of one myotube by several hybrid cells is common. After 24 to $72 \mathrm{hr}$ of cell depolarization with low concentrations of veratridine, myotubes continue to evidence synaptic activity, but the chance of evoking activity, in a given myotube by stimulation of a neighboring hybrid cell, is diminished to $30 \%$ of control values; only 5\% of myotubes can be demonstrated to still have multiple innervation. However, the efficacy of synapses that persists after veratridine exposure is comparable to control. By $24 \mathrm{hr}$ after removal of veratridine, synapse number returns to control levels. Tetrodotoxin prevents these effects. We suggest that components responsible for the well known developmental change from polyneuronal to mononeuronal innervation may be present and accessible to manipulation in this relatively well defined tissue culture system.
\end{abstract}

The immature neuromuscular junction differs from the adult in that it receives multiple innervation. Over time, all but one of these synapses are rejected (Redfern, 1970; Bennett and Pettigrew, 1974; Rosenthal and Taraskevich, 1977). The synapse that remains matures both morphologically (Couteaux, 1960) and electrophysiologically (Bennett and Pettigrew, 1974). Several investigators have proposed that there is a competition between presynaptic nerves, with increased neuronal activity, either in absolute terms or relative to each other, speeding the change from polyneuronal to mononeuronal innervation. In the soleus muscle of rats, for example, the reduction in polyneuronal innervation results from a diminution in the number of muscles innervated by each motor neuron (Brown et al., 1976). This has been ascribed in part to an inherent tendency for each motor neuron to reduce its peripheral field (Brown et al., 1976; Thompson et al., 1979; Jansen et al., 1978) and, in part, to a competitive interaction that occurs between synapses that are in close proximity to each other (Brown et al., 1976; Kuffler et

\footnotetext{
${ }^{1}$ We wish to thank F. Marie Neal for technical assistance in the preparation of myotubes and Jodi Hiltbrand and Rita Lohse for typing the manuscript.

${ }^{2}$ To whom correspondence should be addressed at the Laboratory of Developmental Neurobiology, Building 36, Room 2A21, National Institutes of Health, Bethesda, MD 20205.
}

al., 1977). A role of activity in this process has been suggested because tetrodotoxin (TTX) paralysis of the sciatic nerve results in an increase in polyneuronal innervation of the paralyzed muscle (Thompson et al., 1979). The phenomenon of transient hyperinnervation and subsequent rejection of redundant synapses has been demonstrated during development of synapses other than the neuromuscular junction (Lichtman, 1977; Crepel et al., 1976), and the thesis has been generalized to all developing synapses under the rubric "selective stabilization" in which neuronal activity is the key determinant of the final synaptic architecture (Benoit and Changeux, 1975; Changeux and Danchin, 1976; O'Brien et al., 1978). Postulates for the mechanism of this process have included changes in receptor distribution on the postsynaptic cell (Stent, 1973) as well as failure of transmission or actual anatomic withdrawal of the processes of particular presynaptic cells (Korneliussen and Jansen, 1976; O'Brien et al., 1978).

We describe here our studies on the cholinergic synapse between the neuroblastoma $\times$ glioma hybrid cell and myotubes in tissue culture and the changes induced in these synapses by chronic exposure to the $\mathrm{Na}^{+}$channel activator, veratridine. We selected this system because the synapses formed appear morphologically immature, with some vesicles but without pre- and postsynaptic thickenings, and because several hybrids synapse upon 
the same muscle cell (Nelson et al., 1978). The hybrid cells are electrically excitable but are not spontaneously active, and synaptic connections have not been found between hybrid cells (P. G. Nelson, C. Christian, and M. Nirenberg, unpublished observations). Thus, these cells allowed investigation of a relatively simple stimulus paradigm-chronic veratridine depolarization-that could be interpreted free of the secondary effects of membrane potential on the incidence or patterning of spontaneous activity.

\section{Materials and Methods}

Neuroblastoma $\times$ glioma hybrid cells of the NG108-15 line were grown attached to Falcon flasks in Dulbecco's modified Eagle's mediun (DMEM) supplemented with $5 \%$ fetal bovine serum and hypoxanthine $\left(1 \times 10^{-4} \mathrm{M}\right)$, aminopterin $\left(1 \times 10^{-6} \mathrm{M}\right)$, and thymidine $\left(1.6 \times 10^{-5} \mathrm{M}\right)$ in a humidified atmosphere of $10 \% \mathrm{CO}_{2}, 90 \%$ air. Dibutyryl cyclic adenosine $3^{\prime}: 5^{\prime}$-monophosphate ( $\left.\mathrm{Bt}_{2} \mathrm{cAMP}\right)$ or prostaglandin $\mathrm{E}_{1}\left(\mathrm{PGE}_{1}\right)$ and theophylline enhance differentiation of the hybrid cells (B. Hamprecht, M. Nirenberg, T. Amano, unpublished observations; H. Higashida, S. Wilson, J. Kenimer, and M. Nirenberg, manuscript in preparation). One week prior to co-culturing with myotubes $1 \mathrm{mM} \mathrm{Bt}{ }_{2} \mathrm{cAMP}$ was added to the hybrid cells. Hindlimb muscles of 18- to 21-day-old rat embryos were plated at a density of $2 \times 10^{5}$ per $35-\mathrm{mm}$ (Falcon) plastic Petri dish in a medium of DMEM supplemented with $10 \%$ horse serum (Nelson et al., 1976). Three days after the plating of muscle cells, when myotubes were forming, the co-culture was started by addition of 3 to 4 $\times 10^{4}$ hybrid cells per plate and the medium was changed to DMEM, $10 \%$ horse serum, with $10 \mu \mathrm{M} \mathrm{PGE}_{1}$ and $1 \mathrm{mM}$ theophylline. The medium was changed daily. On the 3rd day of co-culture, veratridine and/or tetrodotoxin (TTX) was added from stock solutions of $100 \mathrm{~mm}$ veratridine in alcohol and $150 \mu \mathrm{M}$ TTX in DMEM. Prior to electrophysiological recording, the dishes were washed twice within $20 \mathrm{~min}$. Therefore, drugs were not present during the recordings. The recording medium consisted of DMEM with added $\mathrm{CaCl}_{2}$ (to a total of $6.8 \mathrm{mM} \mathrm{Ca}{ }^{2+}$ ) and choline (to a total of $125 \mu \mathrm{M}$ ). Simultaneous intracellular recordings were obtained from a myotube and hybrid cell that appeared to make anatomical contact with it. Standard electrophysiological techniques were used as described previously (Nelson et al., 1976). Pairs were evaluated only if the resting potential of the myotube was at least $-40 \mathrm{mV}$ and that of the hybrid was $-35 \mathrm{mV}$, and both had action potentials when stimulated directly. The hybrid cell usually was hyperpolarized to reduce steady state inactivation of the $\mathrm{Na}^{+}$and $\mathrm{Ca}^{2+}$ conductances (Moolenaar and Spector, 1978). The hybrid cell was said to have a synaptic connection with the myotube if its stimulation evoked synaptic potentials in the myotube. The myotube was said to have connections if it evidenced either spontaneous synaptic activity (miniature end plate potentials, mepps) or activity during stimulation of the hybrid cell (end plate potentials, epps). Stimulation was done routinely at $3 / \mathrm{sec}$. It was not necessary to penetrate the myotube directly under the site of contact because of the long length constant of the myotubes and large size of the synaptic potentials.

\section{Results}

The preparation. The hybrid cells differed markedly in size and morphology, varying from round $25-\mu \mathrm{m}$ cells to those more than $100-\mu \mathrm{m}$ in diameter with long and variegate processes. The myoblasts had fused to form myotubes which often were twitching spontaneously unless there was TTX in the medium. The number of cells in plates treated with the standard dose of veratridine $(10 \mu \mathrm{M})$ was not changed noticeably and their morphology appeared unaffected for periods of up to 4 days of treatment; $50 \mu \mathrm{M}$ veratridine caused some vacuolization of the hybrid cells. Ten micromolar veratridine increases ${ }^{22} \mathrm{Na}^{+}$ influx into hybrid cells (Catterall and Nirenberg, 1973) and we found that it acutely depolarized them several millivolts. Although veratridine exposure is utilized frequently as a model of sustained depolarization (Walicke et al., 1977; Forn and Greengard, 1978), persistence of depolarization has not been documented to our knowledge. After $24 \mathrm{hr}$ of exposure to $10 \mu \mathrm{M}$ veratridine, the membrane potential recorded from a series of hybrid cells, was, indeed, depolarized significantly $(23 \pm 5.8 \mathrm{mV}$ (SD), $n=11)$ compared to control levels $(44 \pm 5.4 \mathrm{mV}$, $n=10)(p<0.001)$. A TTX concentration of $1.5 \mu \mathrm{M}$ has been documented to block the $\mathrm{Na}^{+}$action potential (Spector et al., 1973) and the veratridine-induced ${ }^{22} \mathrm{Na}^{+}$ influx (Catterall and Nirenberg, 1973). That the depolarized membrane potential during prolonged veratridine treatment was due to the specific action of veratridine on the $\mathrm{Na}^{+}$channel was demonstrated by focal pressure application of $1.5 \mu \mathrm{M}$ TTX onto individual hybrid cells that were in veratridine for $24 \mathrm{hr}$. The TTX reversed the depolarization $(n=8)$ and returned the cells' membrane potentials to levels comparable to those of control cells $(46 \pm 6.4 \mathrm{mV})$. Ten micromolar veratridine affects ${ }^{22} \mathrm{Na}^{+}$ influx into myotubes only little if at all (Catterall, 1976) and did not affect their membrane potential acutely although, after $24 \mathrm{hr}$, their membrane potential was diminished from $65 \pm 8$ to $45 \pm 5 \mathrm{mV}$.

The resting potentials of the NG108-15 cells after the drugs were washed out varied between -35 and $-75 \mathrm{mV}$ and the cells manifested excitable membrane properties with a fast and slow component action potential if stimulated from a hyperpolarized level to remove inactivation (Moolenaar and Spector, 1978). NG108-15 cells did not have spontaneous spikes either with or without prior drug treatment. The myotubes, on the other hand, frequently were spontaneously active except in those plates treated with TTX.

Pairs of cells were selected by anatomical contiguity, with the NG108-15 cell touching the myotube either through process or cell body, as shown in Figure 1. Figure 2 shows the synaptic activity in a myotube before stimulation of the NG108-15 cell (mepps) and during stimulation. Mepp activity was usually sparse (1 to $15 / \mathrm{min}$ ) and the mepp potentials were sometimes quite large (varying between 0.5 and $35 \mathrm{mV}$ ). Mepp activity was characterized by heterogeneous size distribution, by an increased amplitude (without blockade) by hyperpolarization, and by its occasional potentiation following stimulation of the hybrid cells. These properties clearly distinguish synaptic activity from small non-propagated action potentials sometimes found in these myotubes. 


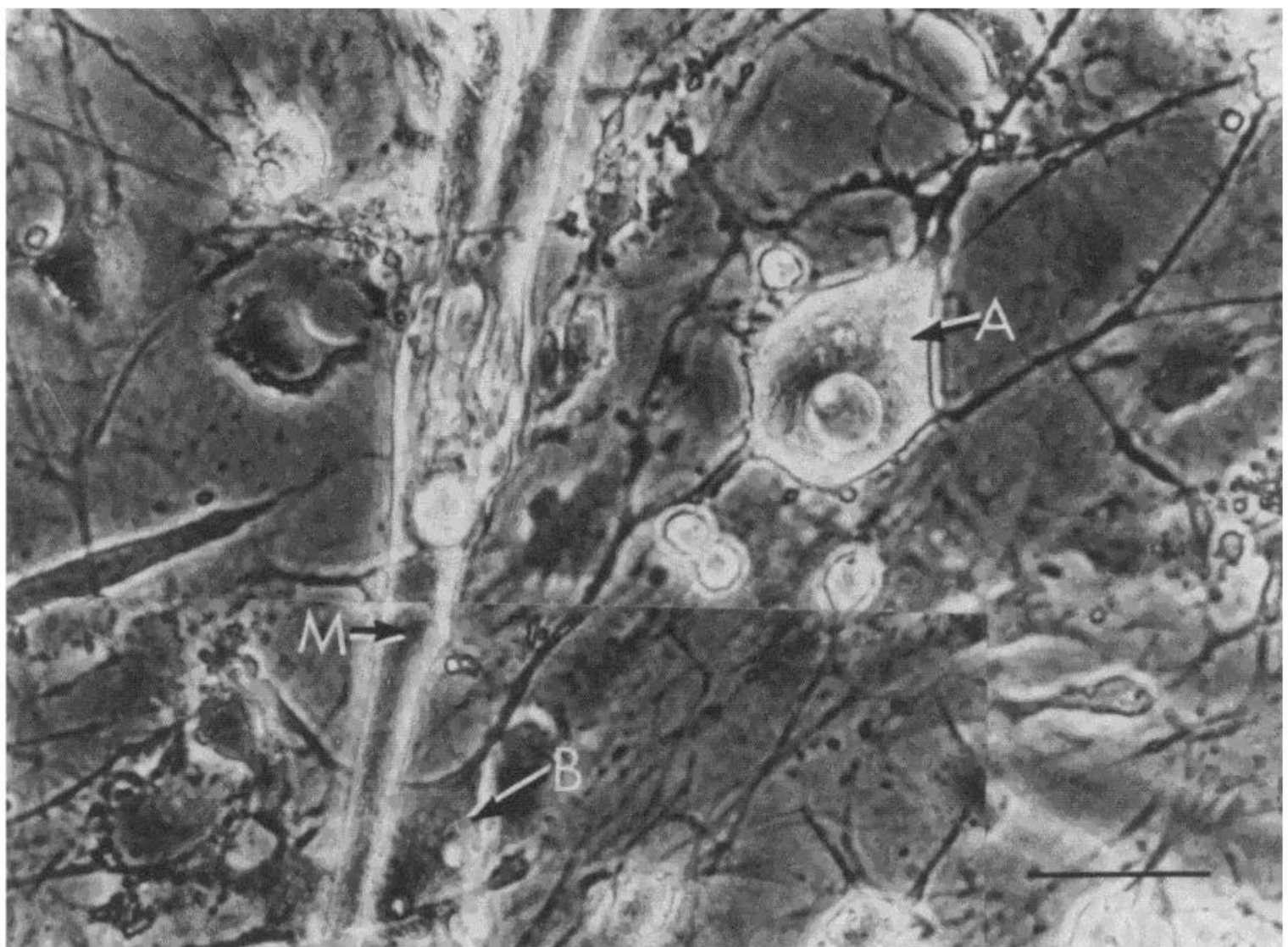

Figure 1. A myotube $(M)$ contacted by several NG108-15 cells. Cell $A$ makes contact with the myotube via a long and tenuous process; cell $B$ touches it via a cell body contact. Stimulation of both could evoke synaptic activity in the myotube. This polyneuronal innervation of a single myotube was not unusual. Scale bar is $50 \mu \mathrm{m}$.
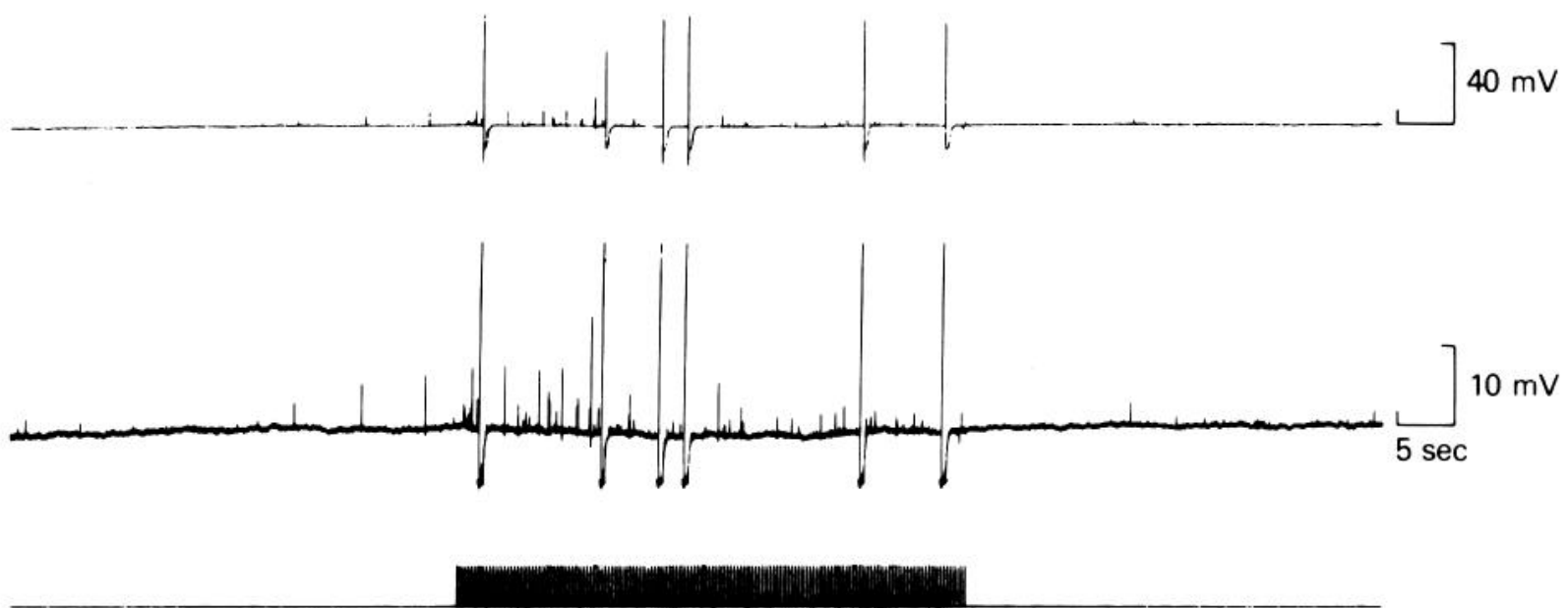

NG108-15 STIMULATION

Figure 2. Penwriter records of spontaneous synaptic activity in a myotube and synaptic activity evoked by stimulation of a NG108-15 cell. Most stimuli do not evoke responses. In some cases, stimulation also elicits action potentials. This pair was in a control plate. Recordings from the myotubes are shown at two sensitivities to show both action potentials and synaptic activity. The resting potential of the myotube was $-60 \mathrm{mV}$.

Most myotubes (between 80 to $100 \%$ ) evidenced such background spontaneous activity under control conditions, with some variability from preparation to preparation in the percentage of cells showing such activity. In most cases, we were able to evoke synaptic activity by stimulation of a neighboring NG108-15 cell (Fig. 3). This resulted in an increase in the number and often of the size of the synaptic potentials. Sometimes these evoked 


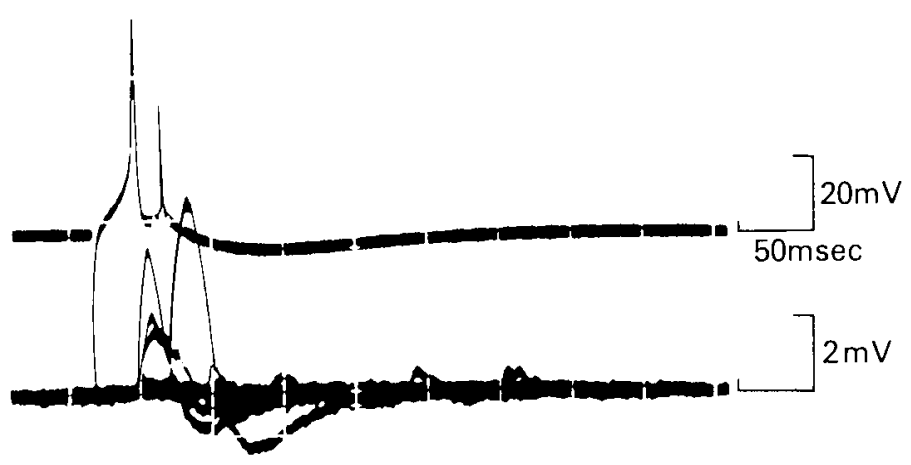

Figure 3. Simultaneous recording from a hybrid cell (above) and myotube (below) showing, during the four superimposed oscilloscope sweeps, both the action potential in the hybrid cell elicited by stimulation and resultant synaptic activity in the myotube. The myotube recording is through an AC-coupled amplifier. Low amplitude spontaneous synaptic activity is shown also. The resting potential of the hybrid cell was -70 $\mathrm{mV}$ and that of the myotube was $-60 \mathrm{mV}$.

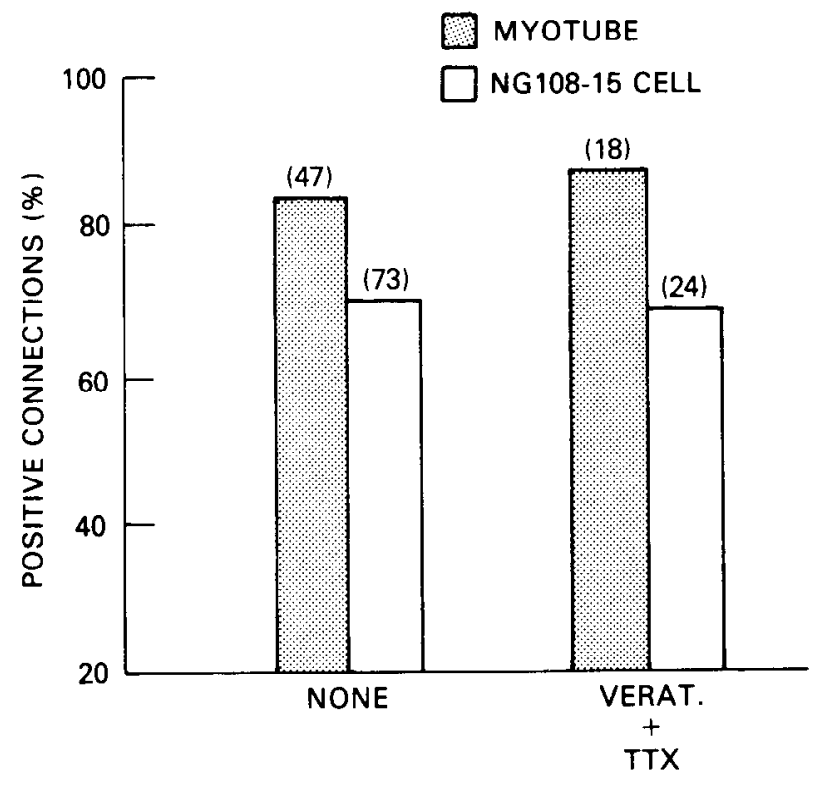

TREATMENT

Figure 4. The percentage of innervated myotubes $(\mathbb{D})$ and the percentage of hybrid cells making synaptic connections ([). The percentages were unchanged from control after treatment with the combination of tetrodotoxin $(T T X)$ and veratridine (VERAT.). For each condition, $n$ is in parentheses.

potentials became large enough to elicit action potentials in the myotube.

The finding that myotubes usually were contacted by several NG108-15 cells and that, as shown in Figure 4, stimulation of most (about 75\%) of the NG108-15 cells evoked activity suggested that the myotubes were multiply innervated since it seemed unlikely that we regularly chose presynaptic cells by chance. We evaluated several myotubes for multiple innervation by sequentially stimulating neighboring NG108-15 cells and found many cases of multiple innervation (see below). For example, both labeled NG108-15 cells in Figure 1 were connected to the same myotube. There was no distinguishing morphological or electrophysiological character- istic of the NG108-15 cells that were connected synaptically: Synaptic activity could be evoked from cells that were small and cells that were large and well differentiated and from those having large rapid action potentials and those with small slow spikes. Some hybrid cells that made synaptic contact touched the myotube only through a process which could be up to $100 \mu \mathrm{m}$ in length; some appeared devoid of processes and seemed to contact the myotube only at the hybrid soma. However, Lucifer Yellow injection revealed a far more extensive network of hybrid processes than was visible with our standard optical system.

Synapse number. For each experimental session, we compared a matching control plate treated identically to the veratridine plates but with the addition of $1.5 \mu \mathrm{M}$ TTX. Figure 4 shows that the combination of TTX and veratridine did not affect the number of synapses. It shows that, in the absence of any added drugs, $84 \%$ of the myotubes had evidence of synaptic input and $70 \%$ of the hybrid cells, when stimulated, could evoke synaptic activity. As shown, similar percentages of myotubes and hybrid cells evidenced connections after 1 day's treatment with TTX and veratridine. TTX alone did not affect synapse number: 12 hybrid-muscle pairs tested, 10 had synapses (83\%) after 2 days of TTX exposure; in matching plates without TTX, 10 of the 12 pairs tested $(83 \%)$ had connections.

Veratridine exposure caused a reduction in the number of NG108-15 cells making effective synaptic contact with myotubes. In the series shown in Figure 5, pairs were tested after exposure to veratridine for 1,2 , or 3 days. The number of synaptic connections in control plates remained stable during this same time period so that, by 3 days, $78 \%$ of the hybrid cells still could evoke activity.

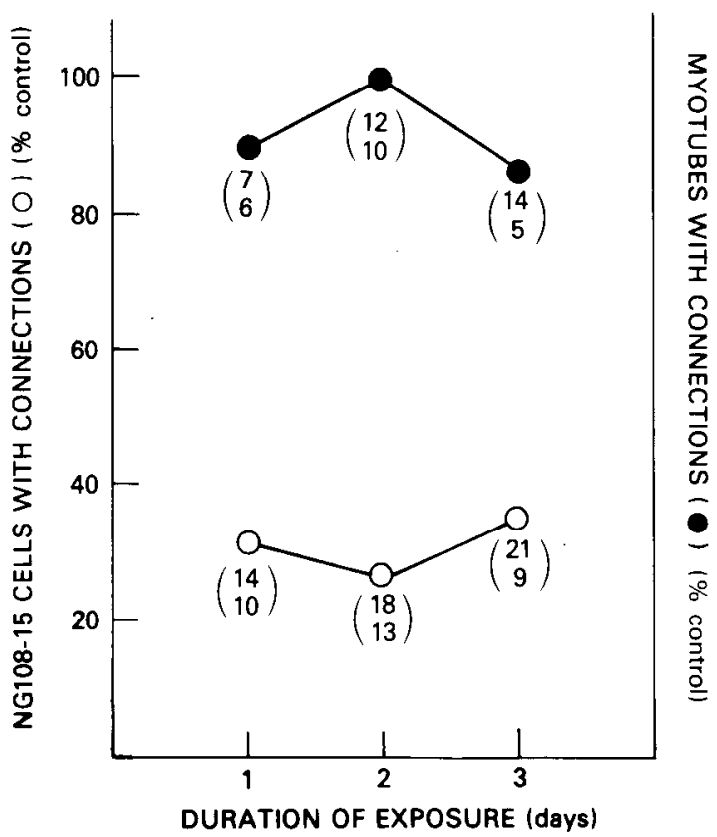

Figure 5. The percentage of hybrid cells with synaptic connections to myotubes $(O)$ was reduced dramatically by treatment with veratridine. The percentage of innervated myotubes (O) was unchanged. The number of measurements is shown beneath each point (test/control). 
As shown, exposure to veratridine diminished the number of NG108-15 cells with connections to about $30 \%$ of the matched controls. The number remained stable even with the longer (2- to 3-day) exposure to veratridine, suggesting that there was neither an ongoing toxic effect nor a return to control levels with time. As shown, the number of myotubes with evidence of some connections (usually marked by ongoing spontaneous activity) remained stable over the same period so that the net effect of veratridine treatment was not to denervate muscle but rather to reduce polyneuronal innervation. We examined this question directly by recording from a series of myotubes while stimulating several hybrid cells adjacent to each of them. Of 13 myotubes so examined under control conditions, all were innervated, 2 as evidenced by mepps (with no evocable synaptic activity), 4 having synaptic activity evoked from only 1 of the hybrid cells, and 7 with activity evoked by stimulation of 2 or more hybrid cells, and hence, directly confirmed as having polyneuronal innervation. After veratridine treatment, 15 of the 16 myotubes examined were innervated, 7 as manifest by mepps alone, 7 with activity evoked by stimulation of only 1 of the NG108-15 cells, but only 1 with activity evoked by stimulation of more than 1 . The mean number of hybrid cells tested with each myotube was 2.3 in the control cultures and 2.2 in the veratridine-treated cultures. While 14 of 30 hybrid cells tested under control conditions demonstrably shared innervation of a myotube with another hybrid cell, only 2 of 34 hybrid cells did so after veratridine treatment $\left(\chi^{2}(1)=16.1 ; p<\right.$ 0.001 ). Thus, just as myotubes evidenced a reduction in the degree of polyneuronal innervation, the hybrids appeared to become less likely to participate in polyneuronal innervation.

Many of the hybrid cells without effective synaptic connection were large and morphologically well differentiated, often apposing the myotube over a relatively large expanse of membrane and usually having a normal action potential with a broad $\mathrm{Ca}^{2+}$ component (Fig. 6).

The $\mathrm{Na}^{+}-\mathrm{K}^{+}$pump of these cells is stimulated by increasing $\mathrm{Na}^{+}$loads (Lichtshtein et al., 1979) as occurs with veratridine, and it seemed possible that metabolic by-products or the use of adenosine $5^{\prime}$-triphosphate resulting from enhanced pump activity might contribute to the loss of synapses. Therefore, in two experiments (total of 20 test pairs), we blocked the $\mathrm{Na}^{+}-\mathrm{K}^{+}$pump with

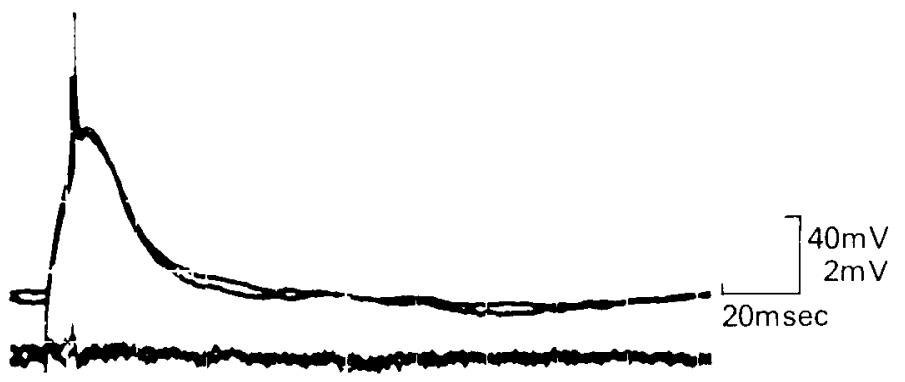

Figure 6. Two superimposed action potentials of a hybrid cell showing normal rapid and slow components. No synaptic activity was elicited in the myotube (below) despite a broad area of anatomical contiguity of the two cells. The resting potential of the hybrid cell was hyperpolarized to $-100 \mathrm{mV}$. ouabain (using doses of 50 and $250 \mu \mathrm{M}$ which are adequate to block the increased activity of the $\mathrm{Na}^{+}-\mathrm{K}^{+}$pump resulting from $\mathrm{Na}^{+}$ionophores acutely (M. C. Fishman, I. Spector, P. G. Nelson, manuscript in preparation)). The number of synapses in cultures treated with veratridine and ouabain was about the same (20\%) as those treated with veratridine alone, suggesting that blocking the pump did not prevent repression of synapses.

We then evaluated synaptic connections at variable intervals after removal of veratridine in order to investigate the persistence of the repression. As shown in Figure $7 A$, most myotubes continued to evidence synaptic input throughout the recovery period. By stimulating the NG108-15 cells to look for evoked activity from particular cells, we found that, by $17 \mathrm{hr}$, evidence of synaptic repression had disappeared (Fig. $7 B$ ).

Synapse efficacy. It was difficult to define the release process as quantitatively as can be accomplished for the mature, in vivo neuromuscular junction because of several characteristics of hybrid-myotube transmission: (1) under all conditions tested, the probability of release was low; (2) as at the immature neuromuscular junction
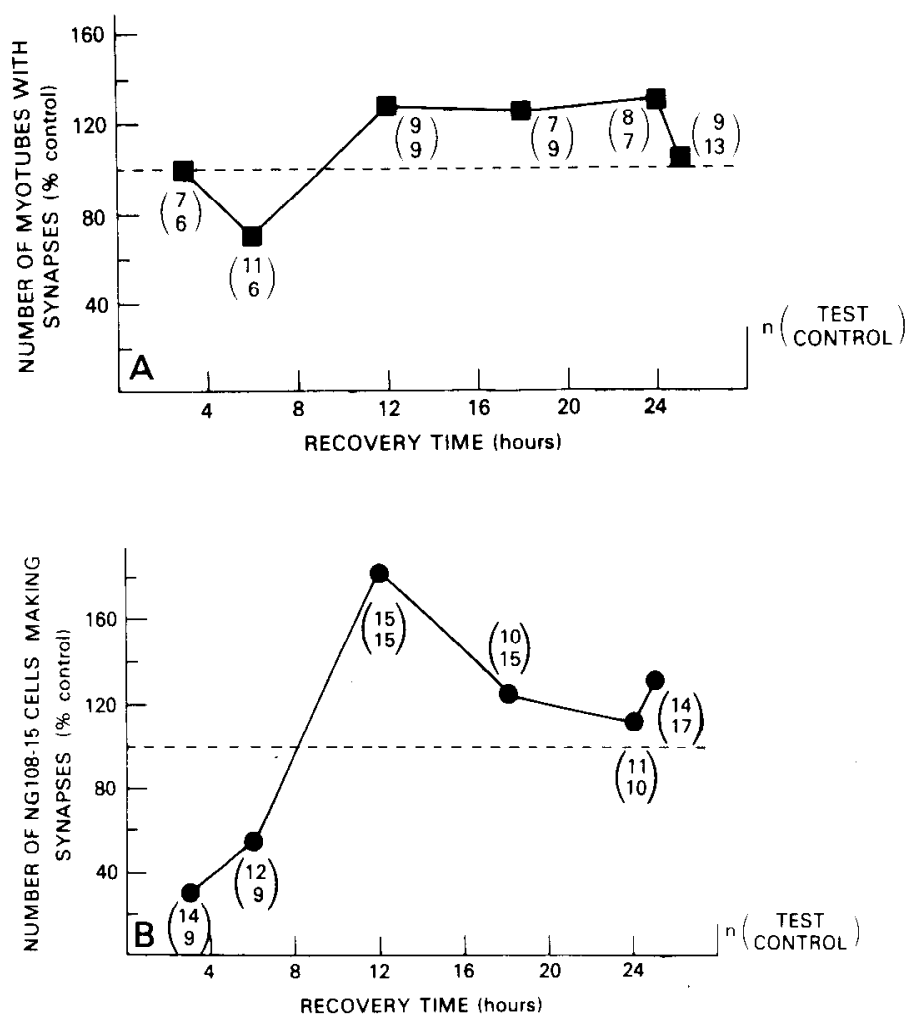

Figure 7. $A$, The number of innervated myotubes as a percentage of control at intervals after removal of veratridine. There was little change during this period. The number of measurements at each time is shown below in parentheses. $B$, The number of hybrid cells with synaptic connections to myotubes as a percentage of control at intervals after the removal of veratridine. There is an early repression and subsequent recovery of the number of synapses as compared to matching control plates. Connections in the control plates remained stable throughout (at about $75 \%$ of pairs tested) except at $12 \mathrm{hr}$ when only $40 \%$ of the control pairs were connected, giving rise to the apparent supernormal number of synapses in the veratridine-treated plates at that time. 
(Dennis et al., 1981), synaptic responses often fatigued before reaching a steady state level adequate for analysis; (3) in many cases, the latency between hybrid stimulation and synaptic response varied by as much as $50 \mathrm{msec}$,

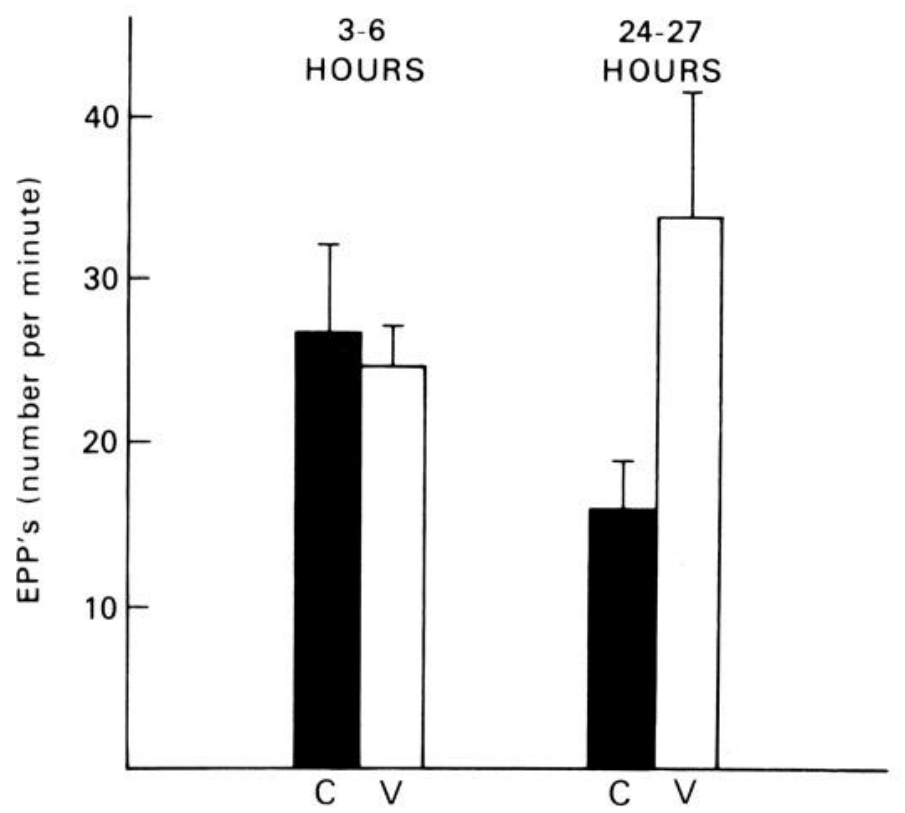

Figure 8. The number of evoked potentials (mean \pm SD) elicited by stimulation of individual hybrid cells at intervals after the removal of veratridine. The data were obtained by alternating between control $(C)$ and veratridine-treated $(V)$ plates within the same time frame, using plates from the same preparation. At 3 to $6 \mathrm{hr}$ after veratridine removal, there is no difference in the number of epps between control and treated plates, despite the reduction in number of synapses. At $24 \mathrm{hr}$, there is a reduction in number of epps in control plates and an increase in veratridine-treated plates. perhaps due to variability in spike transmission down the finer processes; and (4) stimulation also enhanced background synaptic activity.

To obtain a measure of the total amount of transmitter output produced by stimulation, we counted the total number of epps occurring during a period of stimulation and subtracted the number occurring within a comparable period prior to stimulation. This provided one measurable gauge to synaptic efficacy. Since this was variable from day to day (unlike the fairly reproducible and stable overall number of synaptic connections), we evaluated efficacy by alternating between test plates and control plates so that at least two plates for both control and test conditions were studied within the same time window. Figure 8 shows the number of epps elicited during stimulation of hybrid cells that made synaptic connections and compares the number for control and veratridine-exposed pairs both shortly after veratridine removal, when the overall number of synapses was reduced (see above), and $24 \mathrm{hr}$ later, when the overall number of connections had returned to control values. It shows that, during the period when depolarization had caused the repression of many synapses ( 3 to $6 \mathrm{hr}$ ), those that remained continued to function as well as did the controls; by $24 \mathrm{hr}$ after veratridine exposure, the stimulation of hybrid cells in the test plates elicited significantly $(p<0.05)$ more epps than in the control plates. The apparent late veratridine-induced enhancement of synaptic efficacy and the apparent diminution in control efficacy over the $24-\mathrm{hr}$ period is difficult to interpret, but it is clear that the data do not suggest any loss of efficacy after veratridine exposure. For those cells in which postsynaptic responses fell within $50 \mathrm{msec}$ of the presynaptic action potential (as measured on a storage oscilloscope), thereby suggesting that the responses were evoked by that particular action potential and were not due to
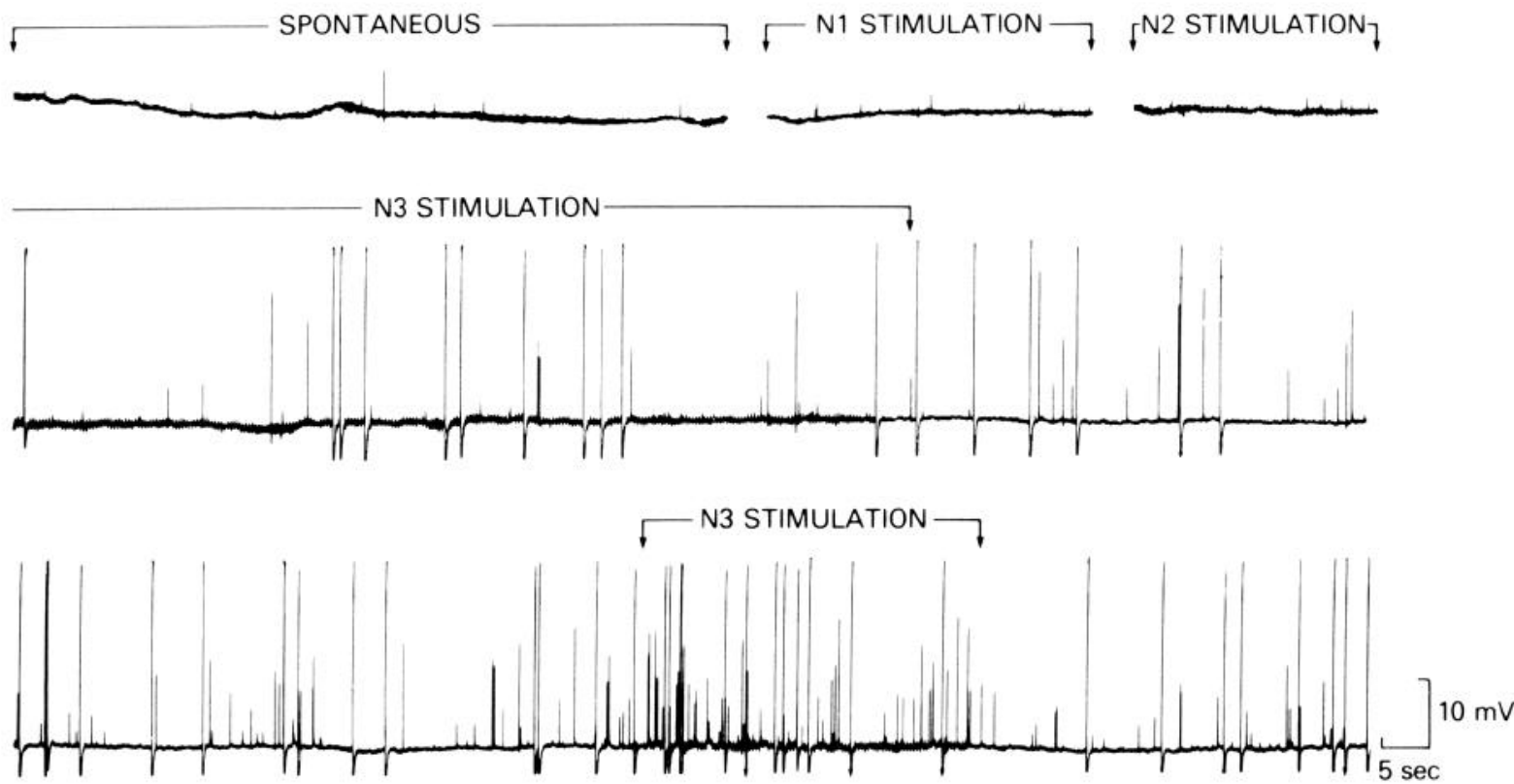

Figure 9. Synaptic activity immediately after the removal of veratridine. Stimulation of hybrid cell N3 evoked activity which persisted after the stimulus ended, and subsequently, could be enhanced by stimulation of N3 again. Neither hybrid cell N1 nor $\mathrm{N} 2$ evidenced synaptic connection to this myotube. The myotube resting potential was $-65 \mathrm{mV}$. 

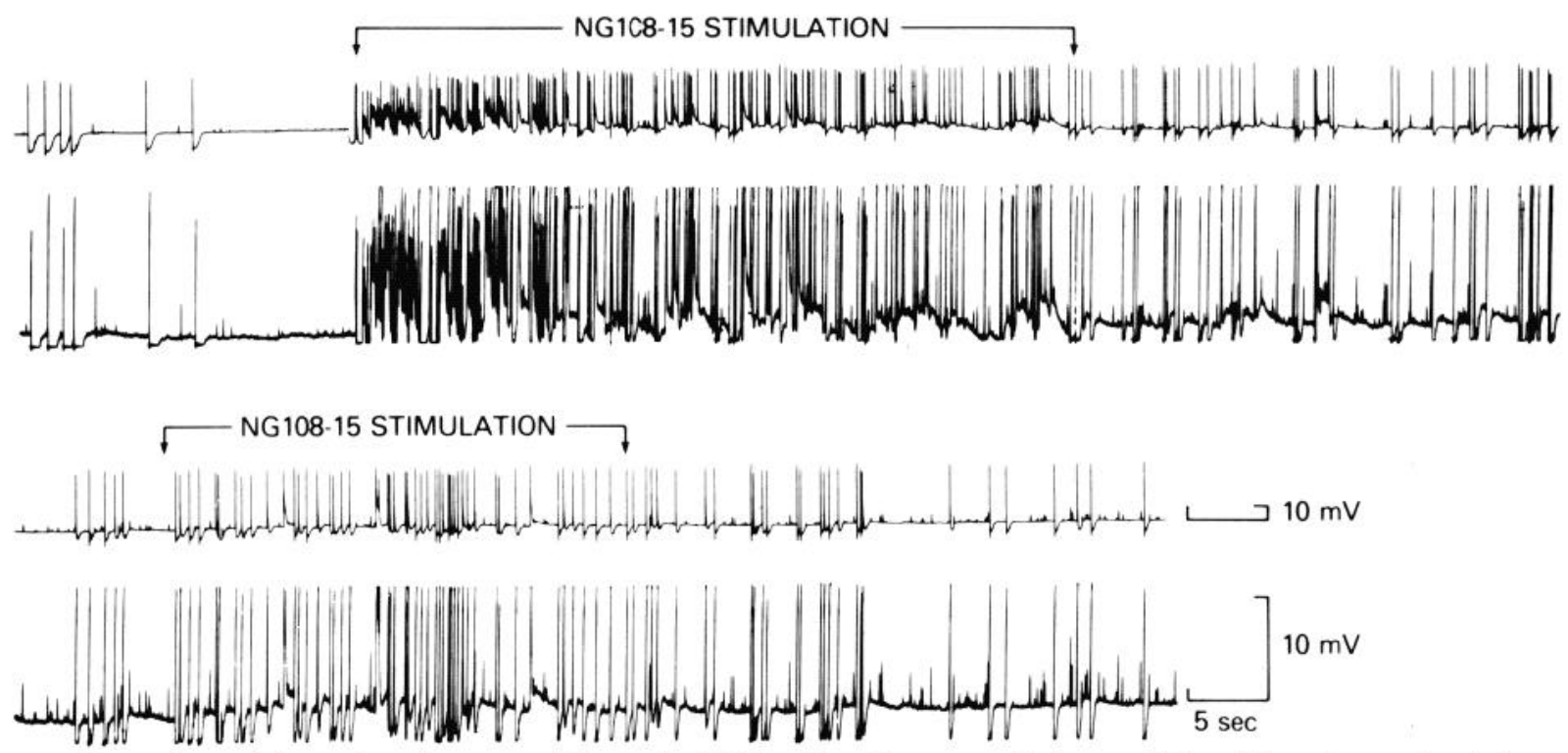

Figure 10. Synaptic activity and action potentials evoked $24 \mathrm{hr}$ after the removal of veratridine. The enhanced activity persisted after the end of stimulation of the hybrid cell. The resting potential of the myotube was $-65 \mathrm{mV}$.

enhanced background activity, we estimated quantal content by the failure method of del Castillo and Katz (1954). Control quantal content at 3 to $6 \mathrm{hr}(n=6)$ was $0.12 \pm 0.10(\mathrm{SD})$ and, at $24 \mathrm{hr}(n=5)$, was $0.17 \pm 0.24$. There was no evidence for change in quantal content after veratridine exposure: quantal content at 3 to $6 \mathrm{hr}$ $(n=5)$ was $0.16 \pm 0.10$ and, $24 \mathrm{hr}$ later $(n=16)$, was 0.17 \pm 0.16 .

Under both control and test conditions, background activity persisted after the end of stimulation as shown in Figures 9 and 10. Enhancement of spontaneous release by presynaptic stimulation is a familiar phenomenon at the neuromuscular junction (Rahamimoff and Yaari, 1973), where it has been attributed to a protracted increase in intracellular calcium concentration that persists after stimulation. Long-lasting ingress of calcium into neuroblastoma cells with maintained depolarization may occur through the voltage-gated, slowly inactivating calcium channels recently described (Fishman and Spector, 1981).

\section{Discussion}

After target cells are contacted during synaptogenesis, some presynaptic terminals are stabilized and others are repressed (Purves and Lichtman, 1980; Mark, 1980). Whether the electrical activity of a nerve, either in absolute terms or relative to its neighbor, is a determinant of this synaptic reorganization remains unknown. In this study, we have demonstrated connectivity changes during and after veratridine depolarization. This type of tonic depolarization is used routinely as a model of nerve cell activation (Daly et al., 1972; Forn and Greengard, 1978; McGee et al., 1978) and has been found to elicit changes similar to those of electrical stimulation during long term studies of neurotransmitter choice in cultured sympathetic nerve cells (Walicke et al., 1977).

The synapses formed between neuroblastoma $\times$ glioma cells and skeletal myotubes in tissue cultures are accessible to the manipulation of growth and recording con- ditions; in addition, since the hybrid cells are not spontaneously active and have not been found to form synapses with each other, the effects during tonic veratridine depolarization are not complicated by additional effects on the shape of the individual action potential or frequency of trains of action potentials.

One to 3 days of continuous depolarization causes a reduction in the incidence of synapses between hybrid cell and muscle. This repression is unaccompanied by any evidence for loss of efficacy at the remaining synapses. Similarly, at the in vivo mammalian neuromuscular junction, the rejection of some synapses during development is not preceded by progressive reduction in quantal content but rather occurs abruptly (Miyata and Yoshioka, 1980; Rosenthal and Taraskevich, 1977).

An additional point of similarity to the in vivo development of the neuromuscular junction is that there is a loss of multiple innervation out of proportion to the overall diminution in innervation. Thus, the high incidence of myotube innervation in control conditions (about 85\%) is undiminished by veratridine depolarization. However, the incidence of demonstrable multiple innervation is reduced from over $50 \%$ to about $5 \%$ by such treatment. One basis for these findings would be that, once a given neuron becomes the sole source of innervation to a muscle, the probability of its becoming nonfunctional is greatly reduced.

Immobilization of myotube cell surface components (Fishman et al., 1981) to a membrane domain adjacent to a particular nerve could participate in synapse elimination, and in other systems, the clustering of receptors undoubtedly contributes to enhanced sensitivity to transmitter under the nerve and reduction of sensitivity elsewhere (Frank and Fischbach, 1979; Fischbach and Cohen, 1973; Anderson et al., 1977). We attempted to investigate this in the hybrid cell-myotube system. There were large numbers of clusters of acetylcholine receptors on myotubes under both control and treated conditions (as labeled with rhodaminated $\alpha$-bungarotoxin) that were 
not in registration with neurites. We saw no dramatic changes in receptor distribution, but subtle changes would not have been evident. This may be because these cells release diffusely a high concentration of "aggregating factor" into the medium (Christian et al., 1978).

These observations suggest that synapse depolarization can cause synapse elimination in an in vitro system. The molecular changes responsible may be triggered by the prolonged influx of $\mathrm{Na}^{+}$. In some systems, the $\mathrm{Na}^{+}$ ion itself can regulate protein synthesis (Piatigorsky et al., 1980). One alternative, however, is that chronic depolarization causes a persistent calcium entry through "non-inactivating" voltage-sensitive $\mathrm{Ca}^{2+}$ channels (Eckert and Lux, 1976; Fishman and Spector, 1981) and that consequent calcium accumulation regulates synaptic stability (Rotter et al., 1979).

\section{References}

Anderson, M. J., M. W. Cohen, and E. Zorychta (1977) Effects of innervation on the distribution of acetylcholine receptors on cultured muscle cells. J. Physiol. (Lond.) 268: 731-758.

Bennett, M. R., and A. G. Pettigrew (1974) The formation of synapses in striated muscle during development. J. Physiol. (Lond.) 241: 515-545.

Benoit, P., and J. -P. Changeux (1975) Consequences of tenotomy on the evolution of multiinnervation in developing rat soleus muscle. Brain Res. 99: 354-358.

Brown, M. C., J. K. S. Jansen and D. van Essen (1976) Polyneuronal innervation of skeletal muscle in new-born rats and its elimination during maturation. J. Physiol. (Lond.) 26: 387-422.

Catterall, W. A. (1976) Activation and inhibition of the action potential $\mathrm{Na}^{+}$ionophore of cultured rat muscle cells by neurotoxins. Biochem. Biophys. Res. Commun. 68: 136-142.

Catterall, W. A., and M. Nirenberg (1973) Sodium uptake associated with activation of action potential ionophores of cultured neuroblastoma and muscle cells. Proc. Natl. Acad. Sci. U. S. A. 70: 3759-3763.

Changeux, J. -P., and A. Danchin (1976) Selective stabilization of developing synapses as a mechanism for the specification of neuronal networks. Nature 264: 705-712.

Christian, C. N., M. P. Daniels, H. Sugiyama, Z. Vogel, L. Jacques, and P. G. Nelson (1978) A factor from neurons increases the number of acetylcholine receptor aggregates on cultured muscle cells. Proc. Natl. Acad. Sci. U. S. A. 75: 40114015 .

Couteaux, R. (1960) Motor end-plate structure. In Structure and Function of Muscle, G. H. Bourme, ed., Academic Press, New York.

Crepel, F., J. Mariani, and N. Delhaye-Bouchard (1976) Evidence for multiple innervation of Purkinje cells by climbing fibers in the immature rat cerebellum. J. Neurobiol. 7: 567578.

Daly, J. W., M. Huang, and H. Shimizu (1972) Regulation of cyclic AMP levels in brain tissue. Adv. Cyclic Nucleotide Res. 1: 375-387.

del Castillo, J., and B. Katz (1954) Quantal components of the end-plate potential. J. Physiol. (Lond.) 124: 560-573.

Dennis, M. J., L. Ziskind-Conhaim, and A. J. Harris (1981) Development of neuromuscular junctions in rat embryos. Dev. Biol. 81: 266-279.

Eckert, R., and H. D. Lux (1976) A voltage-sensitive persistent calcium conductance in neuronal somata of Helix. J. Physiol. (Lond.) 254: 129-151.
Fischbach, G. D., and S. A. Cohen (1973) The distribution of acetylcholine sensitivity over uninnervated and innervated muscle fibers grown in cell culture. Dev. Biol. 31: 147-162.

Fishman, M. C., and I. Spector (1981) Potassium current suppression by quinidine reveals additional calcium currents in neuroblastoma cells. Proc. Natl. Acad. Sci. U. S. A., in press.

Fishman, M. C., P. Dragsten, and I. Spector (1981) Immobilization of concanavalin A receptors during differentiation of neuroblastoma cells. Nature 290: 781-783.

Forn, J., and P. Greengard (1978) Depolarizing agents and cyclic nucleotides regulate the phosphorylation of specific neuronal proteins in rat cerebral cortex slices. Proc. Natl. Acad. Sci. U. S. A. 75: 5195-5199.

Frank, E., and G. D. Fischbach (1979) Early events in neuromuscular junction formation in vitro. J. Cell Biol. 83: 143158.

Jansen, J. K. S., W. Thompson, and D. P. Kuffler (1978) The formation and maintenance of synaptic connections as illustrated by studies of the neuromuscular junction. Prog. Brain Res. 48: 3-18.

Korneliussen, H., and J. K. S. Jansen (1976) Morphological aspects of the elimination of polyneuronal innervation of skeletal muscle fibers in newborn rats. J. Neurocytol. 5: 591604.

Kuffler, D., W. Thompson, and J. K. S. Jansen (1977) The elimination of synapses in multiply-innervated skeletal muscle fibers of the rat: Dependence on distance between endplates. Brain Res. 138: 353-358.

Lichtman, J. (1977) The reorganization of synaptic connexions in the rat submandibular gland during post-natal development. J. Physiol. (Lond.) 273: 153-177.

Lichtshtein, D., K. Dunlop, H. R. Kaback, and A. J. Blume (1979) Mechanism of monensin-induced hyperpolarization of neuroblastoma $\times$ glioma hybrid NG108-15. Proc. Natl. Acad. Sci. U. S. A. 76: 2580-2584.

Mark, R. F. (1980) Synaptic repression at neuromuscular junctions. Physiol. Rev. 60: 355-395.

McGee, R., P. Simpson, C. Christian, C. Mata, P. Nelson, and M. Nirenberg (1978) Regulation of acetylcholine release from neuroblastoma $\times$ glioma hybrid cells. Proc. Natl. Acad. Sci. U. S. A. 75: 1314-1318.

Miyata, Y., and K. Yoshioka (1980) Selective elinination of motor nerve terminals in the rat soleus muscle during development. J. Physiol. (Lond.) 309: 631-646.

Moolenaar, W. H., and I. Spector (1978) Ionic currents in cultured mouse neuroblastoma cells under voltage-clamp conditions. J. Physiol. (Lond.) 278: 265-286.

Nelson, P. G., C. Christian, and M. Nirenberg (1976) Synapse formation between clonal neuroblastoma $\times$ glioma hybrid cells and striated muscle cells. Proc. Natl. Acad. Sci. U. S. A. 73: $123-127$.

Nelson, P. G., C. N. Christian, M. P. Daniels, M. Henkart, P. Bullock, D. Mullinaux, and M. Nirenberg (1978) Formation of synapses between cells of a neuroblastoma $\times$ glioma hybrid clone and mouse myotubes. Brain Res. 147: 245-259.

O'Brien, R. A. D., A. J. C. Ostberg, and G. Vrbova (1978) Observations on the elimination of polyneuronal innervation in developing mammalian skeletal muscle. J. Physiol. (Lond.) 282: 571-582.

Piatigorsky, J., T. Shinohara, S. Bhat, R. Reszelbach, R. Jones, and M. Sullivan (1980) Correlated changes in $\delta$-crystallin synthesis and ion concentration in the embryonic chick lens: Summary, current experiments, and speculations. Ann. N. Y. Acad. Sci. 339: 265-279.

Purves, D., and J. W. Lichtman (1980) Elimination of synapses in the developing nervous system. Science $210: 153-157$. 
Rahamimoff, R., and Y. Yaari (1973) Delayed release of transmitter at the frog neuromuscular junction. J. Physiol. (Lond.) 228: 241-257.

Redferm, P. A. (1970) Neuromuscular transmission in new-born rats. J. Physiol. (Lond.) 209: 701-709.

Rosenthal, J. L., and P. S. Tarasakevich (1977) Reduction of multiaxonal innervation at the neuromuscular junction of the rat during development. J. Physiol. (Lond.) 270: 299-310.

Rotter, A., R. Ray, and M. Nirenberg (1979) Regulation of calcium uptake in neuroblastoma or hybrid cells-a possible mechanism for synapse plasticity. Fed. Proc. 38: 476.

Spector, I., Y. Kimhi, and P. Nelson (1973) Tetrodotoxin and cobalt blockade of neuroblastoma action potentials. Nature 246: 124-126.

Stent, G. S. (1973) A physiological mechanism for Hebb's postulate of learning. Proc. Natl. Acad. Sci. U. S. A. 70: 9971001.

Thompson, W., D. P. Kuffler, and J. K. S. Jansen (1979) The effect of prolonged, reversible block of nerve impulses on the elimination of polyneuronal innervation of new-born rat skeletal muscle fibers. Neuroscience 4: 271-281.

Walicke, P. A., R. B. Campenot, and P. H. Patterson (1977) Determination of transmitter function by neuronal activity. Proc. Natl. Acad. Sci. U. S. A. 74: 5767-5771. 